\title{
Five stages of progressive $\beta$-cell dysfunction in the laboratory Nile rat model of type 2 diabetes
}

\author{
Kaiyuan Yang', Jonathan Gotzmann², Sharee Kuny3, Hui Huang², Yves Sauvé2,3 and \\ Catherine B Chan'1,2 \\ 1Department of Agricultural, Food and Nutritional Science, University of Alberta, Edmonton, \\ Alberta, Canada \\ 2Department of Physiology, University of Alberta, Edmonton, Alberta, Canada \\ ${ }^{3}$ Department of Ophthalmology and Visual Sciences, University of Alberta, Edmonton, Alberta, Canada
}

Correspondence should be addressed to $Y$ Sauvé

Email

ysauve@ualberta.ca

\begin{abstract}
We compared the evolution of insulin resistance, hyperglycemia, and pancreatic $\beta$-cell dysfunction in the Nile rat (Arvicanthis niloticus), a diurnal rodent model of spontaneous type 2 diabetes (T2D), when maintained on regular laboratory chow versus a high-fiber diet. Chow-fed Nile rats already displayed symptoms characteristic of insulin resistance at 2 months (increased fat/lean mass ratio and hyperinsulinemia). Hyperglycemia was first detected at 6 months, with increased incidence at 12 months. By this age, pancreatic islet structure was disrupted (increased $\alpha$-cell area), insulin secretion was impaired (reduced insulin secretion and content) in isolated islets, insulin processing was compromised (accumulation of proinsulin and C-peptide inside islets), and endoplasmic reticulum (ER) chaperone protein ERp44 was upregulated in insulin-producing $\beta$-cells. By contrast, high-fiber-fed Nile rats had normoglycemia with compensatory increase in $\beta$-cell mass resulting in maintained pancreatic function. Fasting glucose levels were predicted by the $\alpha / \beta$-cell ratios. Our results show that Nile rats fed chow recapitulate the five stages of progression of T2D as occurs in human disease, including insulinresistant hyperglycemia and pancreatic islet $\beta$-cell dysfunction associated with ER stress. Modification of diet alone permits long-term $\beta$-cell compensation and prevents T2D.
\end{abstract}

\section{Key Words \\ - insulin resistance \\ - type 2 diabetes \\ - animal model \\ - insulin processing \\ - endoplasmic reticulum stress}

Journal of Endocrinology (2016) 229, 343-356

\section{Introduction}

Type 2 diabetes (T2D) is a metabolic disorder associated with chronic hyperglycemia and disruptions in carbohydrate, lipid, and protein metabolism, resulting from decreased production or altered responsiveness to insulin (Reaven 1988, Goldenberg \& Punthakee et al. 2013). The worldwide prevalence of diabetes has more than doubled from 1980 to 2008 (Danaei et al. 2011), affecting over 387 million people (http://www. diabetesatlas.org/; as of 2014), of which the large majority (90-95\%) have been diagnosed with T2D, and this is closely linked to Westernized diets and sedentary lifestyles (Ma \& Tong 2010).

Animal models are essential to delineate the pathogenesis of (and ultimately provide a cure for) T2D. Rodent models of diabetes have been in existence for half a century; the autosomal recessive spontaneous diabetes $(d b)$ mouse was described by Hummel and coworkers in 1966. Displaying abnormal fat distribution, hyperglycemia, polyuria, glycosuria, and pathological changes in pancreatic islets, this model was described as

Published by Bioscientifica Ltd 
resembling diabetes mellitus in humans (Hummel et al. 1966). By 1977, Herberg and Coleman noted that research on obesity and diabetic syndrome animal models had become 'a field of its own' (Herberg \& Coleman 1977). However, because most rodents are more resistant than humans to diabetes when fed Westernized diets (Skovsø 2014), pancreatic $\beta$-cell toxins and genetic modifications are often used to induce symptoms of T2D in rodents (Cefalu 2006, Srinivasan \& Ramarao 2007, King 2012). Although these rodent models are valuable in elucidating certain aspects of the disease, the pathology and fast onset of overt diabetes do not resemble and fail to capture the detailed progression of human T2D (Cefalu 2006, Srinivasan \& Ramarao 2007, King 2012). Therefore, it can be problematic when translating those results to humans.

The Nile grass rat has the potential to be a highly suitable model for T2D in humans for two main reasons. (i) Diabetes develops spontaneously on chow diet; native diet consists of predominantly flowering plants and seeds (Rabiu \& Rose 1997). In captivity and fed standard rodent diets (higher in calories and lower in fiber compared with their native diet), they develop a metabolic syndrome-like phenotype characterized by hyperinsulinemia preceding hyperglycemia (insulin resistance), as well as other landmark features of metabolic syndrome, including abdominal adiposity and weight gain, increased plasma triglycerides, and elevated cholesterol and hypertension (Chaabo et al. 2010). Within 1 year, hyperglycemia worsens and is associated with glucosuria and eventually ketonuria. (ii) Diabetes in Nile rats has a significantly long progression period, normally requiring 6-12 months to demonstrate hyperglycemia, which can provide various time points for studying the different stages of diabetes.

Importantly, staging of human T2D is hallmarked by deleterious changes in pancreatic islets: islet cell mass and insulin secretion. In humans, using autopsy data, $\beta$-cell mass decreases $25-50 \%$ in T2D (Chang-Chen et al. 2008). In animal studies, deficits in $\beta$-cell mass reach approximately 50\% before T2D ensues (Matveyenko $\&$ Butler 2008). Nevertheless, Rahier and coworkers proposed that decreased $\beta$-cell mass (50-60\%) may still not be sufficient to cause diabetes if individuals are otherwise healthy (Rahier et al. 2008). As was the case in subjects undergoing hemipancreatectomy for the purpose of organ donation, in which $50-60 \%$ of $\beta$-cell mass, as well as $\alpha$-cell mass, was lost in surgery, and yet most of the subjects maintained normal glucose levels for up to 18 years. Their findings support that loss of $\beta$-cell mass does not precipitate T2D, whereas $\beta$-cell dysfunction is important for the onset and progression of T2D, which then leads to $\beta$-cell mass loss (Rahier et al. 2008). Additionally, the onset of clinical T2D predicts a loss of about $50 \%$ capacity of insulin secretion (U.K. Prospective Diabetes Study Group 1995).

In order to establish the veracity of the Nile rat as a diabetes model, a clear understanding of the natural history of glucose metabolism regulation is required. Islets of Nile rats are described as degenerated (Noda et al. 2010), and the concentrations of fed plasma insulin are reported to first compensate for, and then fail to respond to glucose (Chaabo et al. 2010). Dietary manipulation such as caloric restriction or reduction of the energy density of food reduces diabetes incidence (Chaabo et al. 2010). However, there have been no studies investigating whether Nile rats would have similar fundamental changes in pancreatic islets as happens in humans, related to both $\beta$-cell mass and glucose responsiveness. Furthermore, the Nile rat also appears to develop secondary complications of diabetes such as nephropathy (Noda et al. 2010) and retinopathy (Noda et al. 2014). Characterization of the model with respect to glucose metabolism would allow future studies of the pathophysiology of diabetes complications in the context of a humanlike trajectory of blood glucose- and insulin-level changes.

Therefore, the objective of this study was to characterize pancreatic islet phenotype focusing on $\beta$-cell physiology and morphology in the context of diabetes progression in Nile rats. We hypothesized that Nile rats fed standard rodent diet (high-calorie, low-fiber chow) would exhibit a progression from compensated insulin resistance to overt T2D as for humans (Weir \& BonnerWeir 2004). By contrast, we postulated that a high-fiber diet (low calorie, similar to their native diet; Hfib) would prevent pathology in $\beta$-cells and development of T2D.

\section{Materials and methods}

\section{Animals}

A total of 91 male Nile rats (Arvicanthis niloticus), aged 2-12 months, were used in this study. Dr L Smale (Michigan State University, East Lansing, MI, USA) graciously provided the breeders required to establish our colony at the University of Alberta (Edmonton, Alberta, Canada). All animals were maintained on a $14 \mathrm{~h}$ light: $10 \mathrm{~h}$ darkness cycle, with room temperature and relative humidity of $21 \pm 2^{\circ} \mathrm{C}$ and $45-50 \%$, respectively. From weaning at 21-23 days, animals were fed either high-calorie, lowfiber chow (Prolab RMH 2000, 5P06, LabDiet, Nutrition

Published by Bioscientifica Ltd. 
International, Richmond, IN, USA) or high-fiber Hfib (Mazuri Chinchilla Diet, 5M01, Purina Mills, LLC, St Louis, MO, USA). The macronutrient and energy content of the diets are compared in Table 1. Food and water availability was unrestricted until fasting was implemented $16 \mathrm{~h}$ before blood collection and subsequently killing the animals. Experiments were carried out in accordance with the National Institutes of Health (NIH) (Bethesda, MD, USA) guidelines regarding the care and use of animals for experimental procedures and the Association for Research in Vision and Ophthalmology (ARVO) Statement for the Use of Animals in Ophthalmic and Vision Research. All aspects of this research were done under strict approval of the University of Alberta's 'Animal Care and Use Committee' (ACUC protocol \#328).

\section{Fasting blood glucose}

Fasting blood glucose (FBG) levels were measured with an Accu-Chek Compact Plus glucose monitoring system (Roche) from tail blood samples following $16 \mathrm{~h}$ of food deprivation. Animals with an FBG of $>5.6 \mathrm{mmol} / \mathrm{L}$ (100 $\mathrm{mg} / \mathrm{dL}$ ) were considered hyperglycemic.

\section{Body composition analysis}

Body composition and body mass index (BMI) were determined using an EchoMRI Whole Body Composition Analyser with NMR instrumentation (Echo-MRI 4in1-500; Echo Medical Systems LLC, Houston, TX, USA). Fat and lean masses (FLMs) were calculated in relationship with body weight. Of note, undetectable substances such as bone mineral content, claws, and hair do not contribute to the NMR signal. BMI was calculated using the following equation:

$$
\begin{aligned}
\mathrm{BMI}= & \text { body weight }(\mathrm{kg}) / \mathrm{length} \text { from } \\
& \text { nose tip to base of tail }\left(\mathrm{m}^{2}\right)
\end{aligned}
$$

Body composition measures of FLM were assessed using the general equation:

$($ Body weight $)=($ lean $)+($ fat $)+($ free water $)+($ undetectable substances $)+$ (systematic errors)

\section{Tissue collection}

Fasted Nile rats were killed with a lethal dose $(480 \mathrm{mg} / \mathrm{kg})$ of Euthanyl (Bimeda-MTC Animal Health Inc., Cambridge, ON, Canada). After animals had reached surgical plane,
Table 1 Macronutrient distribution and caloric density in diets for Nile rats.

\begin{tabular}{lrrrr}
\hline Content & Hfib & & Chow \\
\cline { 1 - 1 } Fat (\%) & & 4.1 & & 9.6 \\
Protein (\%) & 21.0 & & 19.9 \\
Carbohydrate (\%) & & 42.5 & & 50.8 \\
Fiber (\%) & 15.0 & & 3.2 \\
Energy (kcal/g) & 2.9 & 3.5 \\
\hline
\end{tabular}

the blood was collected through a cardiac puncture and transferred into either $\mathrm{K}_{2}$ EDTA- (insulin) or $\mathrm{Na}_{2}$ EDTA(glucagon) coated BD Microtainer Tubes with Microgard Closures (Becton, Dickinson and Company, Mississauga, ON, Canada). The blood was then immediately centrifuged at $400 \mathrm{~g}$ for $20 \mathrm{~min}$ at $4^{\circ} \mathrm{C}$ to allow separation of plasma. Plasma samples were stored at $-80^{\circ} \mathrm{C}$. Pancreases were collected and either fixed in formalin overnight at $4^{\circ} \mathrm{C}$ for embedding in paraffin by standard techniques or processed for pancreatic islet isolation as described below.

\section{Analysis of plasma insulin and glucagon levels}

Plasma insulin and glucagon levels were assessed by ELISA (Ultra Sensitive Mouse Insulin ELISA Kit \#90080, Mouse Glucagon ELISA Kit \#81504; Crystal Chem, Inc., Downers Grove, IL, USA) according to the manufacturers' instructions.

\section{Glucose-stimulated insulin secretion from isolated pancreatic islets}

Islets were isolated and cultured overnight for insulin secretion studies. The protocol was performed as described previously (Chan et al. 1993, 2001) with the following modifications: (i) pancreases were digested for a total of $15 \mathrm{~min}$ with vigorous shaking to break down acinar tissues; (ii) after digestion, the samples were filtered through a $160 \mu \mathrm{m}$ nylon filter, washed three times with HBSS supplemented with $0.2 \%$ BSA, and centrifuged to collect islet pellets (Salvalaggio et al. 2002). To measure insulin release, triplicate samples of three islets per vial were incubated in Dulbecco's Modified Eagle's medium (Sigma) with different glucose concentrations $(2.8,5.5$, $11,16.5,22 \mathrm{mM}$ ) for $90 \mathrm{~min}$ at $37^{\circ} \mathrm{C}$. Supernatants were retained, and insulin remaining in the islets was extracted with $3 \%$ acetic acid, then stored at $-20^{\circ} \mathrm{C}$ for future insulin radioimmunoassay (RIA) (Chan et al. 1993). Total islet insulin content was calculated by adding insulin secreted into supernatant plus that remaining in the islet pellet, as determined by RIA. From this, the percentage of

Published by Bioscientifica Ltd 
total insulin secreted was calculated for each data point to control for differences in islet size. Insulin stimulation index corresponded to the ratio of the percentage of insulin released in response to $16.5 \mathrm{mM}$ glucose and $2.8 \mathrm{mM}$ glucose.

\section{Immunohistochemistry}

Serial sections $(5 \mu \mathrm{m})$ of formalin-fixed, paraffinembedded pancreas samples were mounted on glass slides. Immunohistochemical staining (IHC) of pancreatic hormones and ER stress proteins was performed as previously described (Whitlock et al. 2012) using the antibodies and conditions listed in Supplementary Table 1 (see section on supplementary data given at the end of this article). For peroxide-based staining, positive immunoreactivity was visualized by diaminobenzidine plus hydrogen peroxide. Slides were dehydrated, mounted, and visualized using a Leica DM6000B microscope equipped with Leica DFC360FX camera (Wetzlar, Germany). The total pancreatic area (excluding large ducts and veins) as well as insulin- and glucagon-positive areas were quantified using ImageJ (NIH, Bethesda, MD, USA), as described previously (Whitlock et al. 2012). The staining intensity of insulin-, proinsulin-, and C-peptide-positive areas was similarly measured. For immunofluorescent staining, slides were mounted with ProLong Gold Antifade Reagent with DAPI (Thermo Fisher Scientific), and visualized using an Olympus IX-81 microscope equipped with a Yokagawa CSU X1 spinning disk confocal scanner (Quorum Technologies, Guelph, ON, Canada). Insulin, glucagon, and DAPI (within islets) staining areas, as well as the staining intensity and colocalization coefficient M1 of ERp44- and PDI-positive areas within pancreatic $\beta$-cells, were measured using Volocity 6.0 (PerkinElmer). Colocalization coefficient M1 measured the percentage of ERp44- or PDI-positive pixels that cooccurred with insulin-positive pixels. The number of nuclei within each of the insulin- and glucagon-positive areas was counted separately to determine whether hyperplasia was present and data were normalized to $1000 \mu \mathrm{m}^{2}$ of $\beta$ - or $\alpha$-cell area, respectively. Average cell sizes were calculated by dividing the insulin- or glucagon-positive area $\left(\mu \mathrm{m}^{2}\right)$ by the number of nuclei as an index of hypertrophy.

\section{Statistical analyses}

All data were expressed as mean \pm standard error of the mean (s.E.M.), with $n$ representing the number of animals. The insulin sensitivity index (ISI) was calculated according to the following equation: $2 /(1+(172.1$ insulin $(\mu \mathrm{U} / \mathrm{L})) \times($ glucose $(\mathrm{mmol} / \mathrm{L}) / 1000))$. HOMA-B was calculated using the equation: $(20 \times$ insulin $(\mu \mathrm{U} / \mathrm{L})) /$ (glucose $(\mathrm{mmol} / \mathrm{L}))$. The correction factor of -3.5 , often used in the denominator, was omitted because low FBG in the Hfib group yielded negative results. Data were analyzed by one-way or two-way analysis of variance followed by Tukey's multiple comparison test, as appropriate.

Table 2 Metabolic phenotype.

\begin{tabular}{|c|c|c|c|c|c|c|c|c|c|}
\hline \multirow[b]{2}{*}{ Outcome } & \multicolumn{3}{|c|}{2 months } & \multicolumn{3}{|c|}{6 months } & \multicolumn{3}{|c|}{12 months } \\
\hline & $\mathrm{Hfib}$ & Chow & $P$-value & Hfib & Chow & $P$-value & Hfib & Chow & $P$-value \\
\hline Body weight (g) & $\begin{array}{c}66.5 \pm 1.7 \\
(n=11)\end{array}$ & $\begin{array}{c}84.1 \pm 2.3 \\
(n=7)\end{array}$ & $<0.01$ & $\begin{array}{l}92.6 \pm 3.9 \\
(n=10)\end{array}$ & $\begin{array}{c}111.5 \pm 1.6 \\
(n=16)\end{array}$ & $<0.01$ & $\begin{array}{c}103.2 \pm 2.5 \\
(n=21)\end{array}$ & $\begin{array}{c}121.8 \pm 1.4 \\
(n=35)\end{array}$ & $<0.01$ \\
\hline BMI (kg/m²) & $\begin{array}{l}5.0 \pm 0.1 \\
(n=4)\end{array}$ & $\begin{array}{l}5.1 \pm 0.1 \\
(n=7)\end{array}$ & NS & $\begin{array}{l}5.4 \pm 0.1 \\
(n=7)\end{array}$ & $\begin{array}{l}5.9 \pm 0.1 \\
(n=13)\end{array}$ & $<0.01$ & $\begin{array}{l}5.2 \pm 0.1 \\
(n=21)\end{array}$ & $\begin{array}{l}5.9 \pm 0.1 \\
(n=18)\end{array}$ & $<0.01$ \\
\hline FBG (mmol/L) & $\begin{array}{l}4.4 \pm 0.1 \\
(n=4)\end{array}$ & $\begin{array}{l}4.1 \pm 0.3 \\
(n=7)\end{array}$ & NS & $\begin{array}{l}3.7 \pm 0.2 \\
(n=6)\end{array}$ & $\begin{array}{l}5.4 \pm 0.9 \\
(n=12)\end{array}$ & 0.04 & $\begin{array}{l}3.8 \pm 0.1 \\
(n=21)\end{array}$ & $\begin{array}{c}10.8 \pm 1.1 \\
(n=35)\end{array}$ & $<0.01$ \\
\hline $\begin{array}{l}\text { Fasting plasma } \\
\text { insulin (ng/mL) }\end{array}$ & $\begin{array}{l}0.7 \pm 0.2 \\
(n=4)\end{array}$ & $\begin{array}{l}3.2 \pm 0.9 \\
(n=5)\end{array}$ & $<0.01$ & $\begin{array}{l}0.5 \pm 0.3 \\
(n=5)\end{array}$ & $\begin{array}{l}1.6 \pm 0.9 \\
(n=9)\end{array}$ & NS & $\begin{array}{l}2.2 \pm 0.7 \\
(n=13)\end{array}$ & $\begin{array}{l}0.9 \pm 0.3 \\
(n=20)\end{array}$ & NS \\
\hline $\begin{array}{l}\text { Fasting plasma } \\
\text { glucagon }(\mathrm{pg} / \mathrm{mL})\end{array}$ & $\begin{array}{c}75.5 \pm 8.7 \\
(n=4)\end{array}$ & $\begin{array}{l}66 \pm 22 \\
(n=5)\end{array}$ & NS & $\begin{array}{l}404 \pm 45.9 \\
(n=3)\end{array}$ & $\begin{array}{l}553 \pm 101 \\
(n=9)\end{array}$ & NS & $\begin{array}{l}182 \pm 38.3 \\
(n=5)\end{array}$ & $\begin{array}{l}254 \pm 33.6 \\
(n=8)\end{array}$ & NS \\
\hline Fat mass $(\mathrm{g})$ & $\begin{array}{l}7.1 \pm 0.5 \\
(n=7)\end{array}$ & $\begin{array}{c}18.7 \pm 1.2 \\
(n=7)\end{array}$ & $<0.01$ & $\begin{array}{l}14.2 \pm 1.8 \\
(n=6)\end{array}$ & $\begin{array}{l}22.6 \pm 1.2 \\
(n=6)\end{array}$ & $<0.01$ & $\begin{array}{l}14.8 \pm 2.7 \\
(n=6)\end{array}$ & $\begin{array}{l}23.8 \pm 1.3 \\
(n=6)\end{array}$ & $<0.01$ \\
\hline Fat mass (\%) & $\begin{array}{c}10.9 \pm 0.6 \\
(n=7)\end{array}$ & $\begin{array}{c}21.1 \pm 1.0 \\
(n=7)\end{array}$ & $<0.01$ & $\begin{array}{c}14.5 \pm 1.5 \\
(n=6)\end{array}$ & $\begin{array}{l}19.4 \pm 0.9 \\
(n=6)\end{array}$ & 0.02 & $\begin{array}{l}14.2 \pm 2.0 \\
(n=6)\end{array}$ & $\begin{array}{l}\text { 19. } 0 \pm 0.9 \\
(n=6)\end{array}$ & 0.02 \\
\hline Lean mass ( $\mathrm{g}$ ) & $\begin{array}{r}50.1 \pm 2 \\
(n=7)\end{array}$ & $\begin{array}{c}61.6 \pm 1.2 \\
(n=7)\end{array}$ & $<0.01$ & $\begin{array}{l}76.6 \pm 1.9 \\
(n=6)\end{array}$ & $\begin{array}{l}86.3 \pm 1.0 \\
(n=6)\end{array}$ & $<0.01$ & $\begin{array}{l}80.3 \pm 2.6 \\
(n=6)\end{array}$ & $\begin{array}{l}92.4 \pm 1.1 \\
(n=6)\end{array}$ & $<0.01$ \\
\hline Lean mass (\%) & $\begin{array}{c}77.2 \pm 1.1 \\
(n=7)\end{array}$ & $\begin{array}{c}73.4 \pm 1.0 \\
(n=7)\end{array}$ & $<0.01$ & $\begin{array}{l}79.5 \pm 1.2 \\
(n=6)\end{array}$ & $\begin{array}{l}74.1 \pm 0.8 \\
(n=6)\end{array}$ & $<0.01$ & $\begin{array}{l}80.2 \pm 2.1 \\
(n=6)\end{array}$ & $\begin{array}{l}73.9 \pm 0.8 \\
(n=6)\end{array}$ & 0.02 \\
\hline
\end{tabular}

Data represented as mean \pm s.E.M., Mann-Whitney $U$ test. NS, not significant. 
A

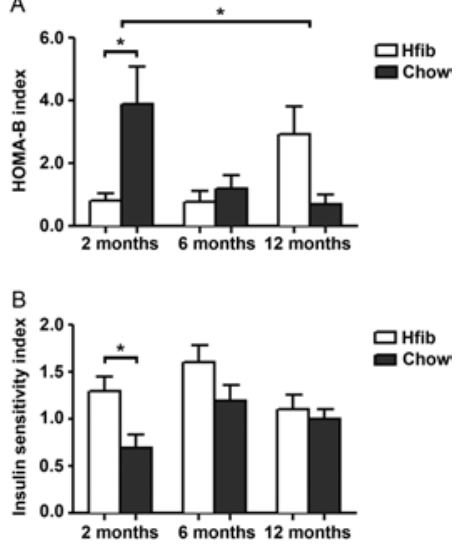

Figure 1

In vivo assessment of pancreatic $\beta$-cell function and insulin sensitivity at 2, 6, and 12 months (Hfib: $n=4,5,13$; Chow: $n=5,9,20$, respectively). Indices were calculated from FBG and plasma insulin values given in Table 1. (A) Effects of age and diet on HOMA-B values for Nile rats fed $\mathrm{Hfib}$ and Chow were assessed to evaluate $\beta$-cell function. Higher HOMA-B indicates superior function. A significant interaction (age and diet) was detected $(P=0.002)$. (B) Effects of age and diet on the ISI to evaluate development of insulin resistance in Nile rats. Chow-fed rats had lower ISI (higher insulin resistance) only at 2 months, compared with animals fed Hfib $(P=0.023)$. Asterisks indicate statistical significance; $P<0.05$.

Nonparametric statistics allowed comparison of single variable values between two groups (Mann-Whitney $U$ test). At $P<0.05$, differences were considered significant. Statistical analyses were performed using GraphPad Prism for Windows version 6.0 (GraphPad Software).

\section{Results}

\section{Body weight and composition}

We investigated the effects of feeding high-fiber (Hfib) versus low-fiber (chow) commercial rodent diets on the body composition of a recently described model of spontaneous T2D (Chaabo et al. 2010); data given in Table 2. Chow-fed Nile rats exhibited higher body weight at all ages $(2,6$, and 12 months). As they reached the mature size at 6 months, the continued rise in body weight was no longer proportional to their length, and BMI was increased at both 6 and 12 months. Changes in BMI were paralleled by increases in body fat mass. Chow-fed animals had 2.6-fold higher fat mass (g/g body weight) and $10.2 \%$ more body fat than those fed Hfib at 2 months. At 6 months, these differences were 1.6-fold and $4.9 \%$, respectively, and remained constant at 12 months. Lean mass ( $\mathrm{g} / \mathrm{g}$ body weight) was also increased in chowfed rats, but when expressed as the percentage of body weight, lean mass was found to be lower.
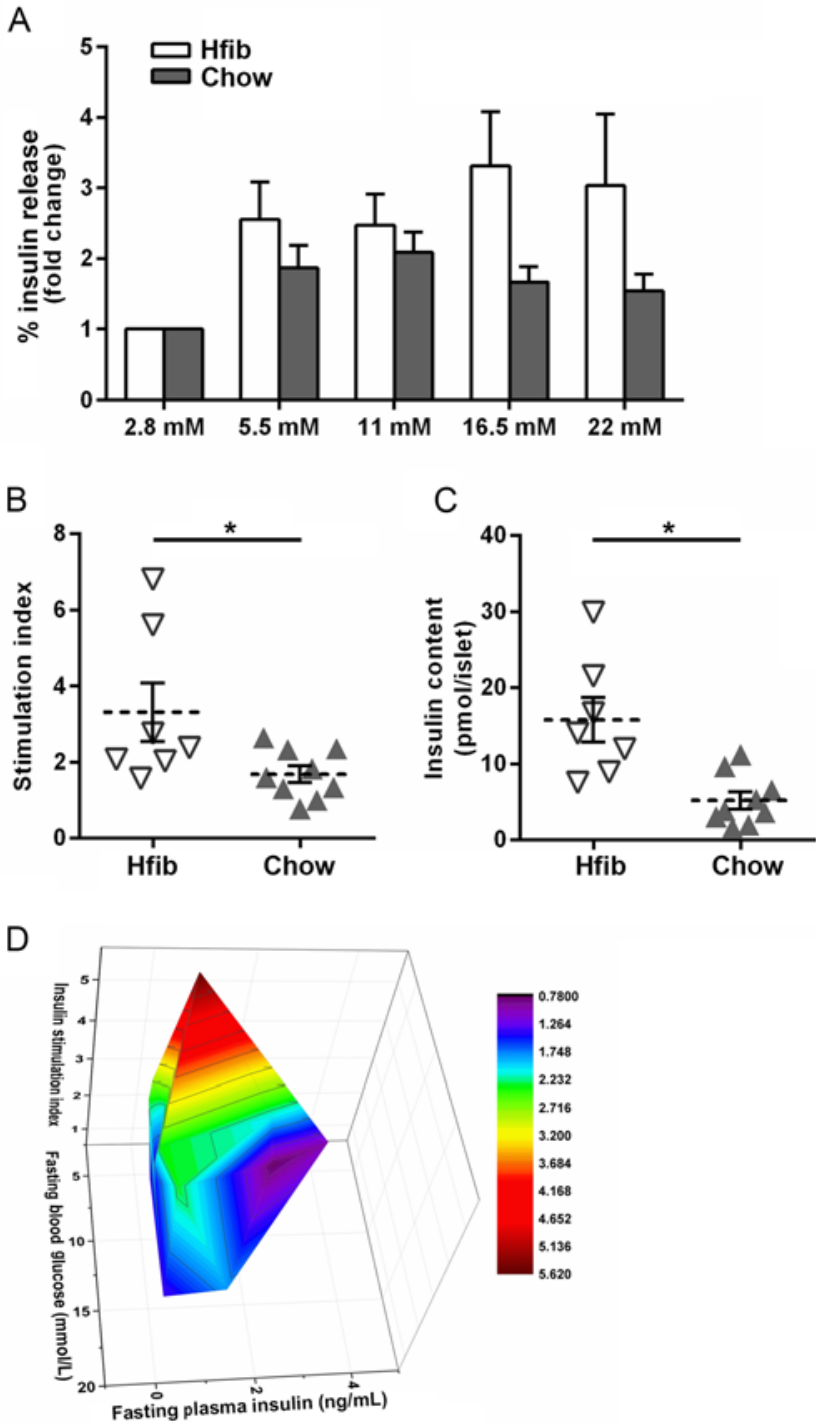

Figure 2

Pancreatic islet function is improved in Nile rats fed $\mathrm{Hfib}$ at 12 months (Hfib, $n=7$; Chow, $n=9$ ). Isolated pancreatic islets were cultured overnight in DMEM with $8.5 \mathrm{mM}$ glucose. Then islets were exposed to DMEM with glucose at 2.8, 5.5, 11, 16.5, and $22 \mathrm{mM}$ for 90 min after a quiescent period of $30 \mathrm{~min}$. Insulin in the supernatant and the islets was measured by RIA. (A) Insulin release was expressed as fold change in response to $2.8 \mathrm{mM}$ glucose. Two-way ANOVA indicated that increasing glucose concentration had a heterogeneous but significant effect on the fold change in insulin; post hoc analysis (Bonferroni correction) failed to show any specific differences between individual glucose concentrations. In addition, the overall effect of diet on insulin secretion did not reach statistical significance $(P=0.08)$, which precluded application of post hoc analysis. (B) Insulin stimulation index, calculated as the ratio of percentage of insulin release in response to $16.5 \mathrm{mM}$ glucose and $2.8 \mathrm{mM}$ glucose, shows a lower stimulation index in Chow. (C) The sum of insulin in the supernatant and the islets was calculated as the total insulin content. The total insulin content was two-fold higher in Hfib. (D) The relationships of stimulation index, fasting glucose, and insulin support that islet preparations with the highest stimulation index were from animals with FBG $<10 \mathrm{mmol} / \mathrm{L}$ and fasting plasma insulin between 1 and $2 \mathrm{ng} / \mathrm{mL}$. Asterisks indicate statistical significance; $P<0.05$.

Published by Bioscientifica Ltd. 
A

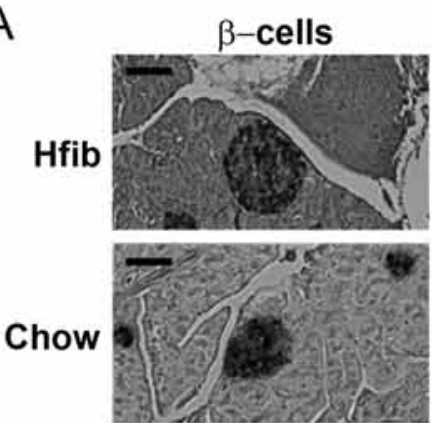

2 months

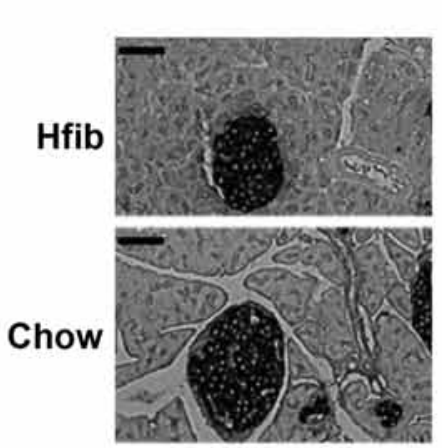

6 months

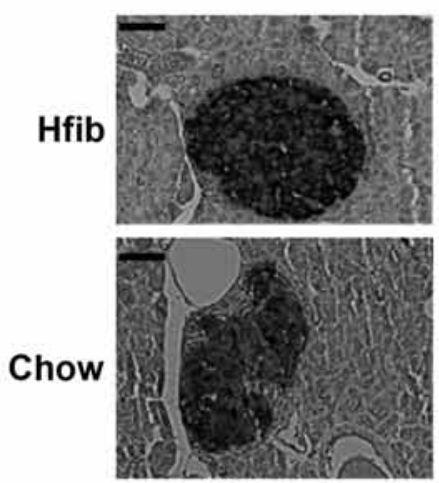

12 months
B

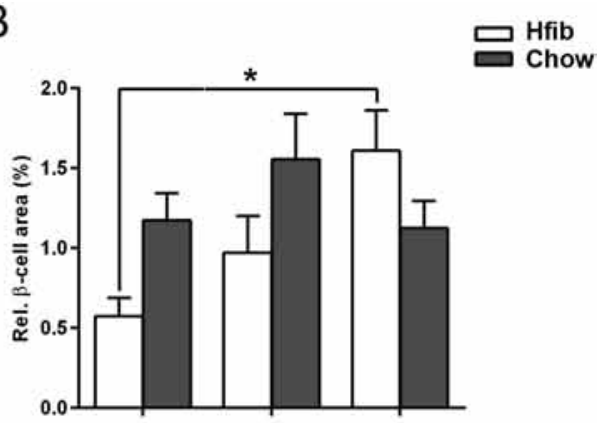

C

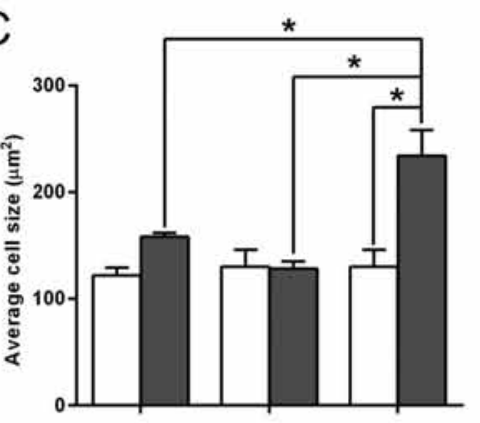

D

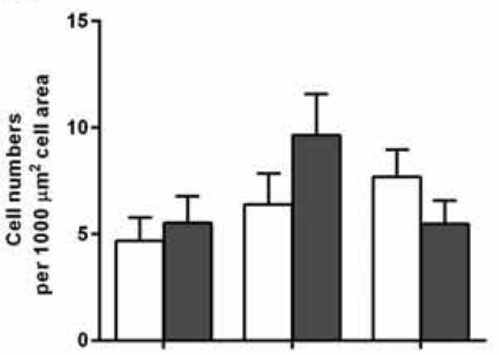

E

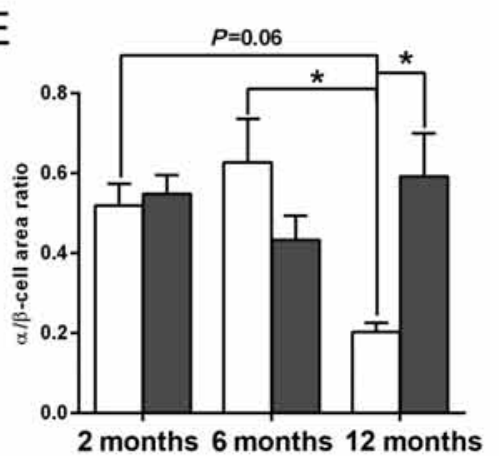

Figure 3

Pancreatic islet $\beta$-cell morphology is altered by diet composition. IHC staining for insulin was performed on single pancreas sections collected from the head of the pancreas adjacent to the spleen. The percentage of pancreatic $\beta$-cell area versus the total pancreas area was calculated to assess pancreatic $\beta$-cell mass. The ratio of $\alpha$-cell area to $\beta$-cell area was calculated to reflect cell composition of pancreatic islets. (A) representative image of insulin staining at 2, 6, and 12 months (Hfib: $n=5,6,9$; Chow: $n=6,11,12$, respectively); (B) pancreatic $\beta$-cell area; (C) size of individual $\beta$-cells; (D) average number of $\beta$-cells per unit area; (E) $\alpha / \beta$-cell area ratio. The $\beta$-cell area was not different at any age when comparing diets; however, more subtle differences in morphology such as reduced staining intensity and enlargement of islet area were observed. Asterisks indicate statistical significance; $P<0.05$. Scale bar $=400 \mu \mathrm{m}$.

\section{FBG and hormone concentrations}

FBG concentrations of both groups were assessed to determine the onset of hyperglycemia, and whether or not it could be prevented by dietary means (Table 2 ). FBG of Nile rats fed Hfib did not exceed $5.6 \mathrm{mmol} / \mathrm{L}$ at any age, whereas chow-fed Nile rats exhibited FBG $>5.6 \mathrm{mmol} / \mathrm{L}$ in $17 \%$ of Nile rats at 6 months and $83 \%$ at 12 months.
To further investigate factors influencing the elevated FBG levels in chow-fed animals, fasting plasma insulin and glucagon concentrations were assessed. Chowfed Nile rats showed a transient increase (4.6-fold) in circulating insulin concentration at 2 months, compared with animals fed Hfib; levels were not different at 6 and 12 months. Glucagon concentrations were not different between diet groups at any age. 
A

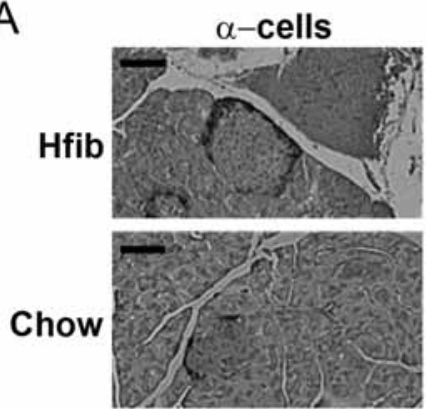

2 months

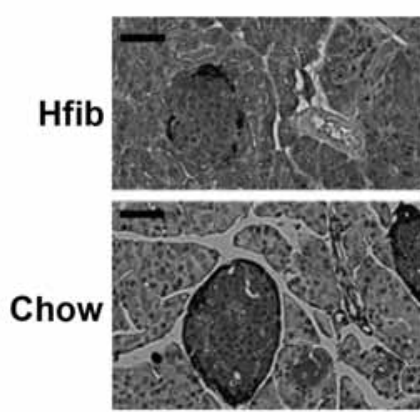

6 months

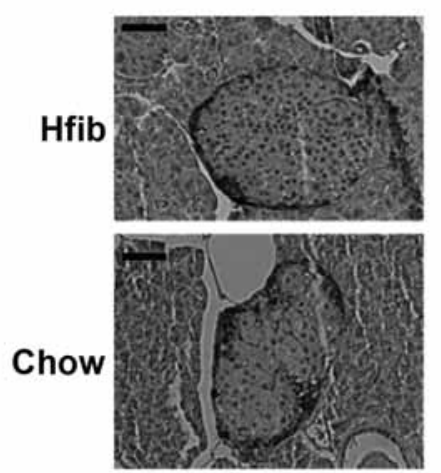

12 months
B

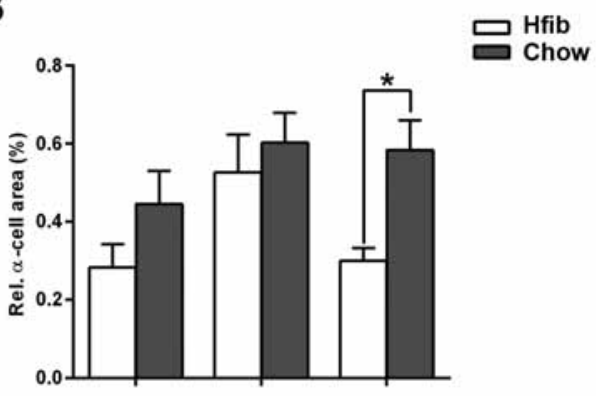

C

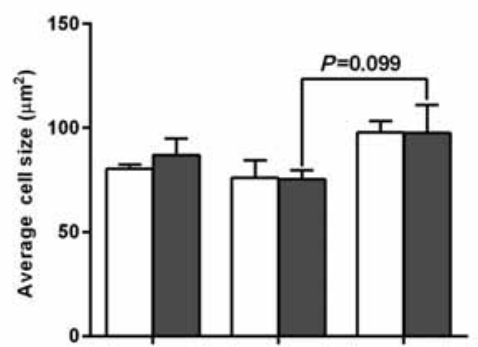

D

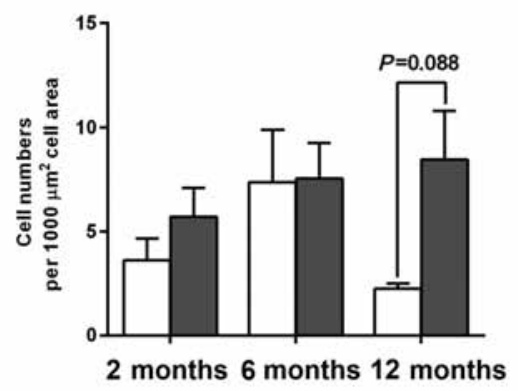

Figure 4

Pancreatic islet $\alpha$-cell composition is altered by diet type. IHC staining for glucagon was performed on single pancreas sections collected from the head of the pancreas adjacent to the spleen. The percentages of pancreatic $\alpha$-cell area versus the total pancreas area were calculated as estimates of pancreatic $\alpha$-cell mass. (A) Representative image of glucagon staining at 2, 6, and 12 months (Hfib: $n=5,6,9$; Chow: $n=6,11,12$, respectively); (B) pancreatic $\alpha$-cell area; (C) size of individual $\alpha$-cells; (D) average number of $\alpha$-cells per unit area. Increased $\alpha$-cell mass was detected at 12 months. Age-related differences were detected in Nile rats fed Hfib but not in those fed Chow. Asterisks indicate statistical significance; $P<0.05$. Scale bar $=400 \mu \mathrm{m}$.

\section{HOMA-B and ISI}

Due to high levels of stress induced by handling the still very feral Nile rats (compared with inbred mice and rats), glucose and insulin tolerance tests could not be implemented. Therefore, we relied on HOMA-B as an index of $\beta$-cell function, with higher values reflecting better glucose responsiveness. A significant interaction between diet and age $(P=0.002)$ was consistent with increased responsiveness in chow-fed Nile rats at 2 months, and attributable to an initial $\beta$-cell compensation that deteriorated with age. Increases in HOMA-B also occurred in animals fed Hfib but only at 12 months (Fig. 1A).

To estimate insulin resistance, the ISI was calculated (Fig. 1B). Lower ISI values are associated with insulin resistance validated against hyperinsulinemic, euglycemic clamp methodology. Chow-fed Nile rats had a lower ISI at 2 months, suggestive of already developed insulin resistance, whereas at 6 and 12 months, ISI was not different between diets.

\section{Pancreatic islet function}

We studied glucose-stimulated insulin secretion of isolated islets as a means to determine whether the high incidence of diabetes in chow-fed Nile rats at 12 months could be caused by pancreatic islet dysfunction (Fig. 2A). There was a significant effect of glucose concentration $(F(1,14)=5.97, P<0.001)$ albeit with considerable heterogeneity between animals in each group $(F(14,56)=4.18, P<0.001)$; post hoc analysis 
A

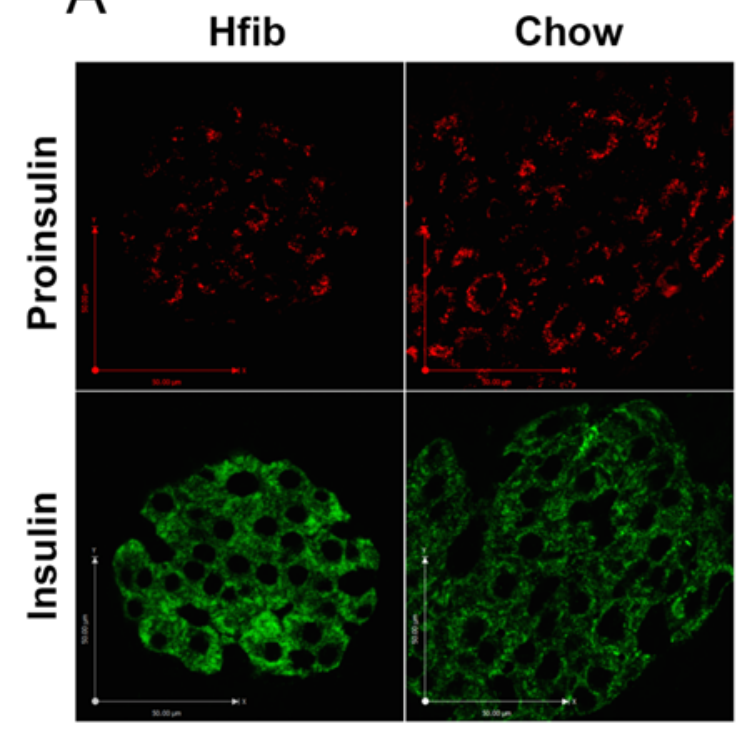

B
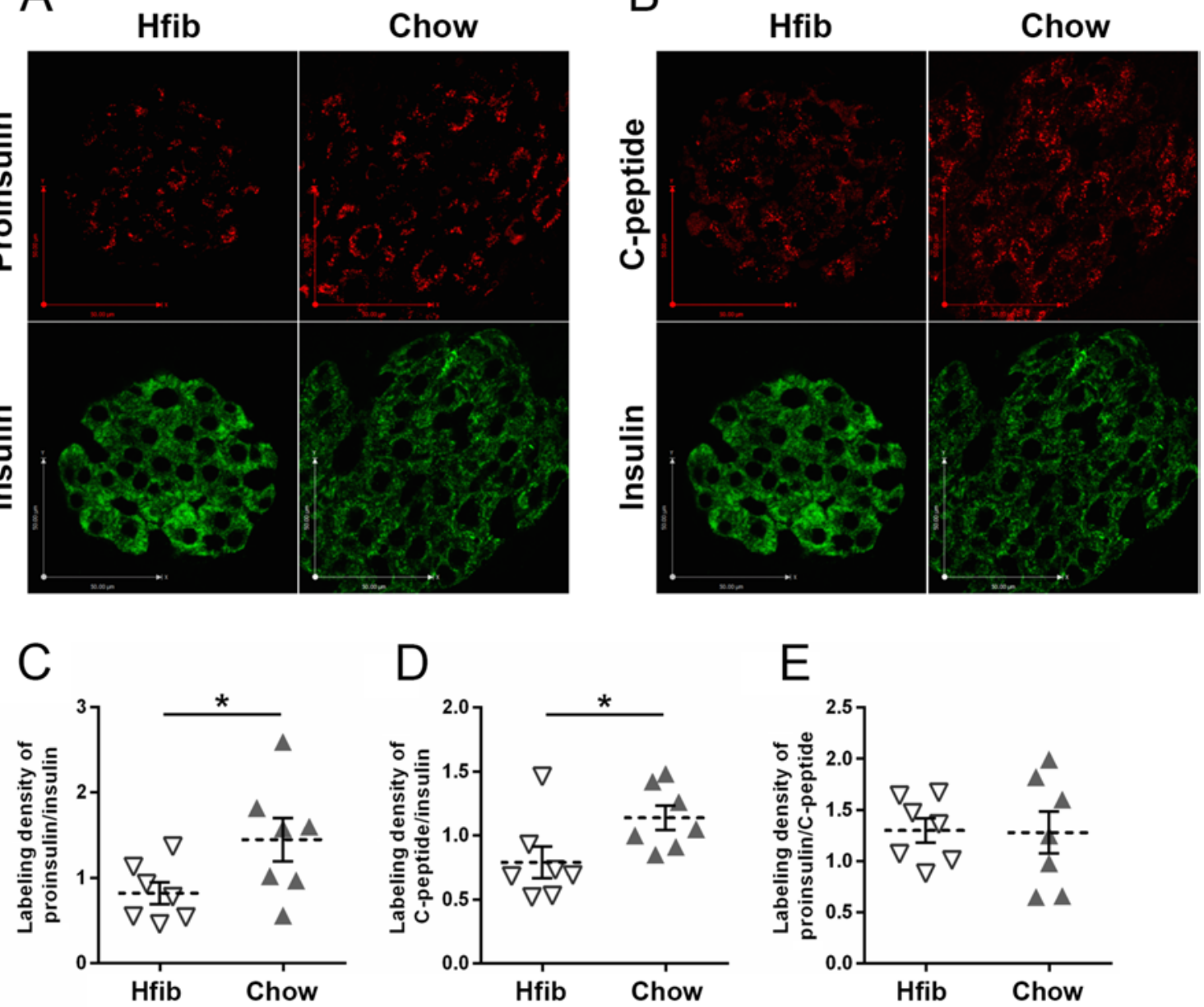

\section{Figure 5}

Increased proinsulin (including i-proinsulin) and C-peptide inside pancreatic islets indicate impaired insulin processing in Chow-fed Nile rats. Representative images of immunofluorescent staining of proinsulin ( $A$, red) or C-peptide (B, red) and insulin ( $A$ and $B$, green) using pancreas sections from 12-month Nile rats (Hfib, $n=7$; Chow, $n=7$ ). Density of proinsulin- (C) and C-peptide (D) -positive staining was expressed as fold change versus the density of total insulin staining. (E) Ratio of proinsulin to C-peptide was also determined. Increased proinsulin relative to insulin implies increased cellular content of not fully processed proinsulin, whereas increased C-peptide suggests retention of insulin in $\beta$-cells. Data presented here are from animals in which severity of diabetes fell into category $3(n=3), 4(n=2)$, and $5(n=2)$; see Fig. 7 for more details. Dashed lines indicated the means and solid lines the standard error of the mean. Asterisks indicate statistical significance; $P<0.05$. Scale bar $=50 \mu \mathrm{m}$.

indicated that this difference was global as opposed to attributable to specific points. Consistent with such variability, the effect of diet was not significant $(F(1,14)=3.54, \quad P=0.08)$, nor was an interaction between diet and glucose detected $(F(4,56)=2.10$, $P=0.09$ ). However, when expressed as a stimulation index normalized to basal secretion, chow-fed response to glucose was reduced by about 50\% (Fig. $2 \mathrm{~B}, P<0.05$ ). Additionally, islets from Nile rats fed Hfib had an insulin content that was two-fold higher (Fig. 2C, $P<0.05)$. To better document the relationship between the insulin stimulation index and in vivo parameters, insulin stimulation index was plotted against FBG and plasma insulin as shown in Fig. 2D. Islet preparations with the most robust secretion index were observed in Nile rats with $\mathrm{FBG}<10 \mathrm{mmol} / \mathrm{L}$ and fasting plasma insulin between 1 and $2 \mathrm{ng} / \mathrm{mL}$.

\section{Pancreatic islet cell composition}

In order to elucidate the pathophysiology involved in diabetes progression, total pancreatic $\beta$ - and $\alpha$-cell areas were quantified at 2,6 , and 12 months using immunoreactivity for insulin and glucagon, respectively (representative images in Figs 3A and 4A). At 2 and 6 months of age, although both diet groups had similar 
A
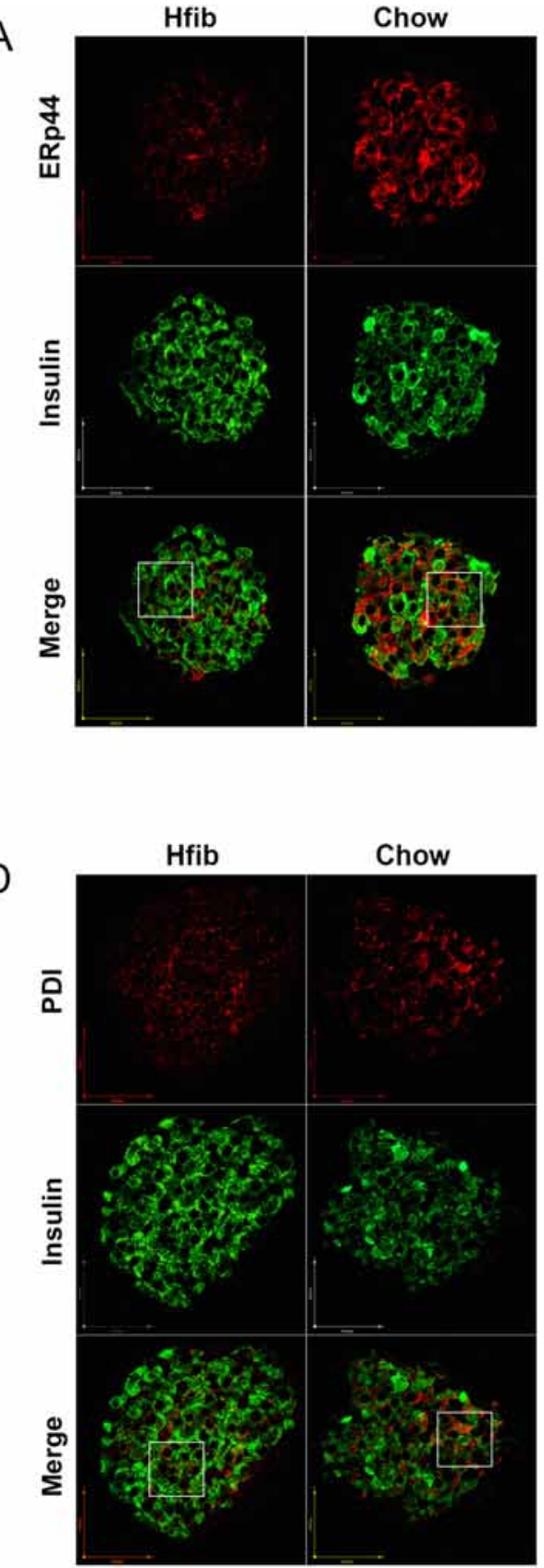

B
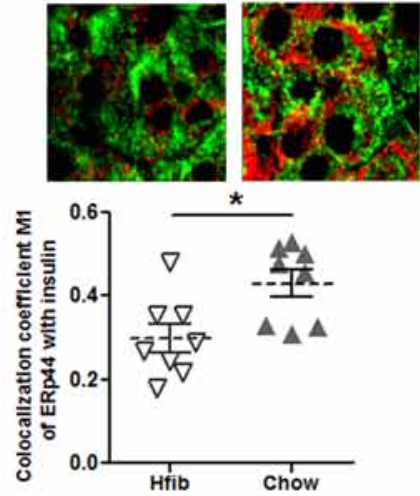

C

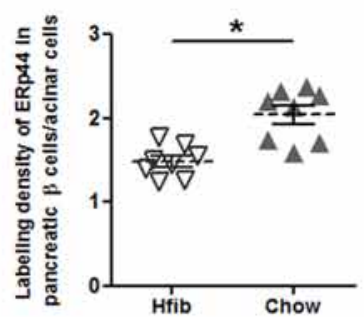

$E$
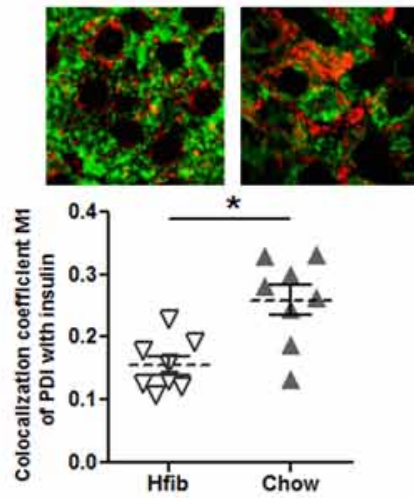

F

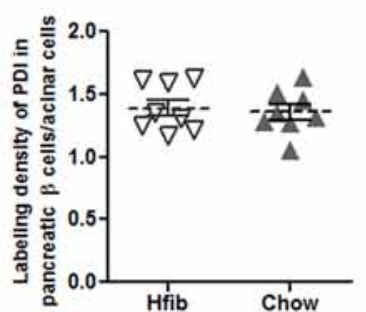

\section{Figure 6}

Altered expression of ER chaperones involved in insulin processing in Chow-fed Nile rats. Representative images of immunofluorescent staining of ERp44 (A, red) or PDI (D, red) and insulin (green) at 12 months (Hfib, $n=8$; Chow, $n=8$ ). Colocalization coefficients of ERp44 (B) and PDI (E) in pancreatic $\beta$-cells were quantified, and the density of staining ( $C$ and $F$ ) was expressed as fold change versus the density of acinar tissues, which was not different between groups. Increased colocalization of ER proteins with insulin within the islets is also suggestive of impaired insulin processing (insets of $B$ and $E$ showing details from $A$ and $D$ ). Dashed lines indicated the means and solid lines the standard error of the mean. Asterisks indicate statistical significance; $P<0.05$. Scale bar $=50 \mu \mathrm{m}$. pancreatic islet cell composition, morphological changes in islet structure were observed. Islet area in pancreases from chow-fed Nile rats appeared enlarged at 6 months, but not all cells in the core were positively stained for insulin, whereas at 12 months, the morphology of islets in this group was further disrupted by an increased area of $\alpha$-cells.

The effects of age and diet on $\beta$-cell area were quantified. No separate effects of age or diet were detected, but a significant diet-age interaction was seen $(F(2,48)=3.75, \quad P<0.05)$, consistent with the steady increase in $\beta$-cell area in Nile rats fed Hfib (Fig. 3B, $P<0.05$ by post hoc analysis). We then measured the average $\beta$-cell size and number to determine if the changes in area were attributable to hyperplasia or hypertrophy, or both. Age $(F(2,24)=11.42, P<0.001)$ and diet $(F(1,24)=8.91, P<0.01)$ affected $\beta$-cell size (Fig. 3C) with a significant interaction of age and diet

Published by Bioscientifica Ltd. 
A

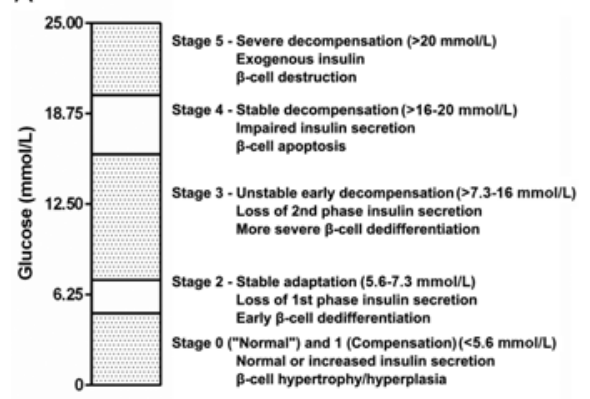

B

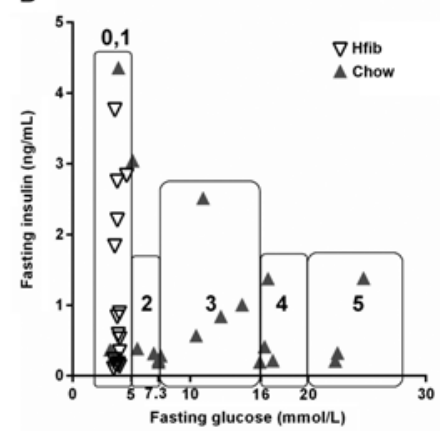

C

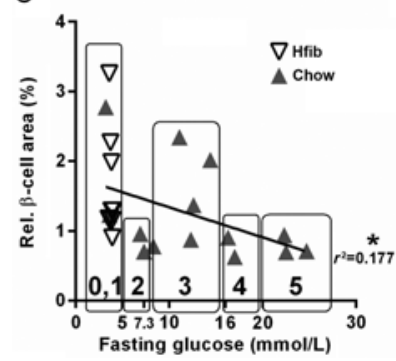

D

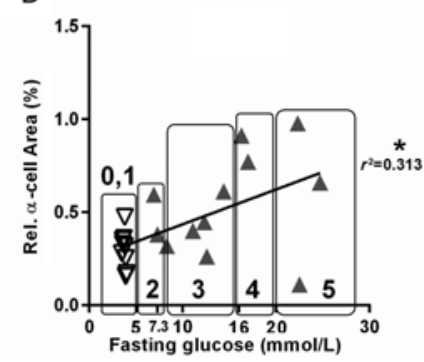

E

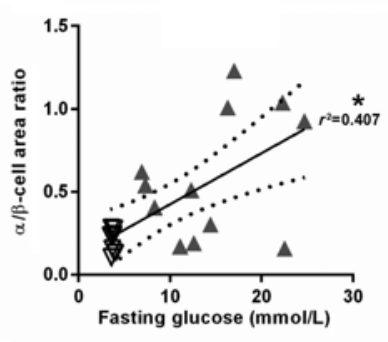

F

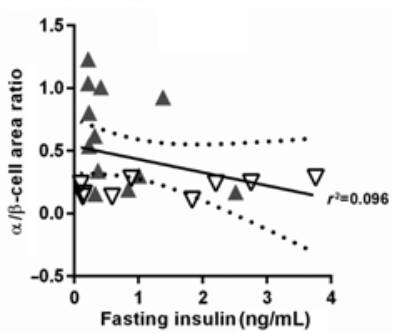

Figure 7

The five stages of diabetes progression at 12 months and correlations of fasting insulin, glucose, and pancreatic islet cells in Nile rats fed Chow. The scheme of a five-stage progression of diabetes (A) was adapted from Weir and Bonner Weir (2004). FBG concentrations of Chow-fed Nile rats at 12 months were plotted against the corresponding fasting plasma insulin (B), pancreatic $\beta$-cell area (C), $\alpha$-cell area (D), and $\alpha / \beta$-cell area ratio (E). Fasting plasma insulin concentrations were plotted against the $\alpha / \beta$-cell area ratio (F). The stages of diabetes were indicated in B-D by rectangular boundaries and numbers. Linear correlations were calculated, with straight lines representing the best-fit lines and dotted curves representing $95 \%$ confidence bands. All animals fed Hfib remained normoglycemic but exhibited a wide range of insulin concentrations, indicative of stage 0 or 1 , and consistent with the distribution of $\beta$-cell area. The majority of Chow-fed animals were stages $2-5$ as insulin secretory capacity and $\beta$-cell area declined. Conversely, relative $\alpha$-cell area and the ratio of $\alpha / \beta$-cell area tended to increase with FBG. Asterisks indicate statistical significance; $P<0.05$.

$(F(2,24)=3.50, P<0.05)$. In chow-fed Nile rats, $\beta$-cell size was significantly increased at 12 months compared with 2 and 6 months of age $(P<0.01 ; P<0.0001$, respectively). Furthermore, when comparing the two diets, the chow group had significantly increased $\beta$-cell size compared with Hfib group at 12 months of age $(P<0.01)$. Significant differences in $\beta$-cell number per unit islet area were not detected. However, the pattern of change within diet groups was similar to the pattern of change observed in total $\beta$-cell area (Fig. 3B). With respect to overall islet composition, as reflected by the $\alpha / \beta$-cell ratio, a significant diet-age interaction was present $(F(2,43)=6.78, P<0.01)$ with a lower ratio in animals fed Hfib at 12 months (Fig. 3E, $P<0.01$ ).

Likewise, $\alpha$-cell area, individual size, and relative number were examined. At 12 months, $\alpha$-cell area was different between the two diet groups $(F(1,48)=6.38$, $P<0.02$; Fig. 4B). The size of each $\alpha$-cell was influenced by age $(\mathrm{F}(2,22)=4.47, P<0.05)$ but not diet (Fig. 4C). Finally, the number of $\alpha$-cells (Fig. 4D) was influenced by neither age nor diet $(F(1,22)=3.78, P=0.06)$.

\section{Pancreatic islet insulin processing}

Increases in immunolabeling density of both proinsulin (including intermediate, partially processed forms of proinsulin (i-proinsulin)) and C-peptide (using specific antibodies) relative to total islet insulin (immunolabeled with an antibody detecting both mature insulin and proinsulin species) were observed in islets from chowfed Nile rats at 12 months (Fig. 5A, B, C and D, $P<0.05$ ), whereas proinsulin/C-peptide ratio did not differ between groups (Fig. 5E). In the endoplasmic reticulum (ER), newly synthesized proinsulin associates with chaperone proteins to enable posttranslational modifications and folding (Steiner et al. 2009). Expression levels and processing of these ER proteins are altered when ER homeostasis is disturbed (Higa \& Chevet 2012) in response to either increased insulin demand (Scheuner \& Kaufman 2008, Eizirik \& Cnop 2010, Kaufman et al. 2010) or impaired posttranslational processing of proinsulin in pancreatic $\beta$-cells (Hong et al. 2007). To further understand how insulin processing was affected in both groups at 12 months, we measured two ER chaperone proteins

Published by Bioscientifica Ltd 
involved in insulin processing: ER resident protein 44 (ERp44) and protein disulfide isomerase (PDI). We found that within pancreatic $\beta$-cells, colocalization coefficients of both ERp44 and PDI with insulin were higher in chow compared with Hfib ( $P=0.014$ and $P=0.003$, respectively) (Fig. 6A, B, D, and E). Furthermore, these two chaperones were differentially expressed in $\beta$-cells: staining density of ERp44 within $\beta$-cells was higher in chow than in Hfib $(P<0.001)$, whereas PDI staining density was similar between groups $(P>0.05)$ (Fig. 6C and F). Qualitatively, differences in staining pattern were also apparent (insets of Fig. 6B and E). For both ERp44 and PDI, staining in the Hfib group tended to localize around the nucleus of $\beta$-cells, whereas in chow $\beta$-cells, there was staining throughout the cytoplasm in many cells.

\section{Correlations between fasting insulin, glucose, and pancreatic islet cells}

An adaptation from Weir and Bonner-Weir (2004) describes the five stages of diabetes progression in chowfed Nile rats at 12 months (Fig. 7A). FBG in Hfib never exceeded $5.6 \mathrm{mmol} / \mathrm{L}$ (Fig. 7B). However, both Hfib and chow displayed heterogeneity in fasting insulin levels. Approximately one-third of Hfib-fed Nile rats had fasting insulin $>2 \mathrm{ng} / \mathrm{mL}$, which is indicative of an effective compensation in this subset of animals. Chow-fed Nile rats exhibited a wide range of FBG, with a pattern of fasting insulin that reflected compensation $(>2 \mathrm{ng} / \mathrm{mL}$ ) through to various phases of decompensation. To address the heterogeneity between animals, we computed linear regression coefficients between pancreatic morphology endpoints and in vivo metabolic parameters (Fig. 7C, D, $\mathrm{E}$ and $\mathrm{F})$. FBG was negatively correlated with pancreatic $\beta$-cell area $\left(r^{2}=0.177, F(1,21)=4.51, P<0.05\right.$; Fig. 7C) and positively correlated with both pancreatic $\alpha$-cell area $\left(r^{2}=0.313, F(1,21)=8.64, P<0.01\right.$, Fig. 7D) and $\alpha / \beta$-cell area ratio $\left(r^{2}=0.407, F(1,21)=13.1, \quad P<0.01\right.$; Fig. 7E). Fasting insulin was not correlated with $\alpha / \beta$-cell area ratio $\left(r^{2}=0.096, F(1,21)=2.02, P=0.17\right.$; Fig. $\left.7 \mathrm{~F}\right)$ and $\beta$ - or $\alpha$-cell area (data not shown).

\section{Discussion}

Weir and Bonner-Weir (2004) proposed a five-stage model of diabetes progression in human, based on sequential changes in $\beta$-cell mass and function, insulin secretion, and circulating glucose concentrations. Stage 0 (normal) and 1 (compensation) occur when insulin is secreted at higher rates to compensate for a relative insulin deficiency in insulin-resistant individuals. In stage 2 , glucose levels start to rise due to loss of $\beta$-cell mass and an initial disruption of $\beta$-cell function. This stage represents a stable state of $\beta$-cell adaptation. Stage 3 consists of early decompensation in which glucose levels rise rapidly to the diabetic levels of stage 4 , which is described as stable decompensation due to increasing $\beta$-cell dysfunction. Finally, stage 5 corresponds to severe decompensation due to a profound reduction in $\beta$-cell mass with progression to ketosis. In this study, 12-month chow-fed Nile rats displayed the full spectrum of progression from stage 1 to 5. Moreover, development of diabetes, while variable between animals, occurred slowly and could be prevented by early dietary intervention, as observed in human T2D.

This study provides a comprehensive investigation of T2D progression in Nile rats, consisting of in vitro quantification of pancreatic glucose-stimulated insulin secretion and of islet morphological changes. Previous work had established that male Nile rats exhibit many features of metabolic syndrome, including hypertension, hyperlipidemia, and hyperglycemia which proceeded to overt diabetes by approximately 6 months (Chaabo et al. 2010, Noda et al. 2010, Bolsinger et al. 2013). FBG values above $5.6 \mathrm{mmol} / \mathrm{L}(100 \mathrm{mg} / \mathrm{dL})$ were considered hyperglycemic based on clinical criteria for metabolic syndrome in humans (Alberti et al. 2009). Higher FBG values have been suggested for humans: $\geq 7.0 \mathrm{mmol} / \mathrm{L}$ is considered diabetic and 6.1-6.9 prediabetic (Goldenberg \& Punthakee et al. 2013). The lower cutoff was adopted for this herbivorous rodent because a natural break was observed; all Nile rats fed Hfib and the majority of Nile rats fed chow up to 6 months demonstrated FBG values below $5.6 \mathrm{mmol} / \mathrm{L}$. In contrast to $\mathrm{FBG}$, calculation of the ISI revealed that even as early as 2 months (5 weeks postweaning), the majority of chow-fed Nile rats were already insulin resistant. At this young age, there was still full compensation by enhanced insulin secretion (exemplified by elevated HOMA-B), without enlargement of islets or alteration of their cellular composition $(\alpha / \beta$-cell ratio was normal). Insulin resistance was concurrent with 2.6-fold greater fat mass and 1.3-fold greater body weight. These Nile rats could be classified as stage 1 moving into stage 2 (Weir \& Bonner-Weir 2004). The experimental design of Chaabo and coworkers did not include assessment of such young animals (Chaabo et al. 2010); however, these authors reported mild increases in body and fat pad weights in diabetes-prone Nile rats ( $\sim 7$ months). As our chow-fed Nile rats aged, the incidence of hyperglycemia increased to more than $80 \%$.

Published by Bioscientifica Ltd 
Concomitant with insufficient $\beta$-cell compensation (declining HOMA-B), islets became dysmorphic. Interestingly, secretory dysfunction in vivo preceded loss of $\beta$-cell mass. By 12 months, many animals were excreting $4+$ ketones in urine (data not shown), consistent with severe decompensation (stage 5) (Weir \& Bonner-Weir 2004) and the loss of glucose-stimulated insulin secretion observed in vitro.

In chow-fed animals, a transient compensation in insulin secretion occurred at 2 months and was followed by defective insulin secretion over the next 10 months. This is in agreement with our observation of a significant difference in HOMA-B (increased in animals fed chow compared with Hfib) at 2 months only. By contrast, in Hfib animals, HOMA-B remained stable over time. Such transient compensation in glucose responsiveness as well as insulin release, seen only in animals fed chow, is followed by a further inability to compensate and therefore by the development of hyperglycemia (i.e., diabetes per se).

The dichotomy between $\beta$-cell area and FBG likely reflected sustained $\beta$-cell compensation in Nile rats fed Hfib, most probably by increasing $\beta$-cell number because no changes in $\beta$-cell size were observed. By contrast, in chow fed animals, $\beta$-cell decompensation was evidenced by hypertrophy of $\beta$-cells concurrent with impaired $\beta$-cell function at 12 months. Whether $\alpha$-cell area changes over time is less clear and more difficult to assess because of their low abundance compared with $\beta$-cells. In any case, no significant differences in circulating glucagon were detected between groups.

The increased demand for insulin biosynthesis to maintain glucose homeostasis places a high load on the ER of islet $\beta$-cells for proinsulin synthesis. An unfolded protein response could be initiated if such demand exceeds capacity, potentially leading to cell apoptosis (Pfützner et al. 2004, Prentki \& Nolan 2006). Elevated circulating proinsulin is an indicator for risk of developing diabetes in humans (Wareham et al. 1999, Pfützner et al. 2005, Prentki \& Nolan 2006, Strawbridge et al. 2011, von Berghes et al. 2011). Proinsulin mutation in Akita mice results in accumulation of misfolded proinsulin that activates ER stress-induced $\beta$-cell death (Hong et al. 2007). In this study, pancreatic $\beta$-cell failure at 12 months in chow-fed animals was associated with impaired proinsulin processing. These Nile rats had elevated proinsulin-to-(insulin+proinsulin) ratios, indicative of defective proinsulin processing, especially in view of their overall low islet insulin content. In addition, the ER chaperone proteins ERp44 and PDI (involved in insulin processing) were more likely to colocalize with insulin (i.e., higher percentage of ERp44- or PDI-positive pixels that cooccurred with insulin-positive pixels) in islet $\beta$-cells in chow-fed Nile rats. This may indicate that additional chaperone proteins are required in $\beta$-cells to compensate for reduced secretion in chow-fed Nile rats. However, within $\beta$-cells, only ERp44 and not PDI (estimated by staining density) were increased; therefore, Nile rats as a model of ER stress could help to clarify the specific responses and functions of each of the key proteins involved in insulin processing in diabetes. The observed increase in C-peptide-to-(insulin+proinsulin) ratio, together with the low stimulation index of isolated islets, supports impaired insulin secretion in chow-fed Nile rats.

In this study, we compared the effects of feeding a high-calorie, low-fiber (chow) diet of a type known to induce diabetes in Nile rats (Chaabo et al. 2010, Noda et al. 2010) with a high-fiber (Hfib) control diet that more closely resembles the Nile rats' native diet. Comparison of the two groups until 12 months showed that a high-fiber diet alone was effective in reducing the incidence of hyperglycemia from 83 to $0 \%$. All Nile rats fed Hfib had normoglycemia with complete preservation of pancreatic islet morphology and function. Insulin resistance in animals fed Hfib was improved at 2 months (compared to chow-fed animals), yet not at the later time points, consistent with the findings of Bolsinger and coworkers, which showed that short-term feeding (7weeks) of high-fiber diets preserved normoglycemia without reducing insulin resistance (Bolsinger et al. 2013). Caloric restriction of a Western-type (chow) diet also reduced progression to diabetes when introduced at 20 weeks of age for 18 weeks of feeding (Chaabo et al. 2010). Thus, Nile rats appear unable to adapt to calorically dense low-fiber diets (fed ad libitum): they rapidly (within 5 weeks postweaning) accumulate fat and develop insulin resistance. Heterogeneity of $\beta$-cell adaptation may be an important determinant of the onset of diabetes, and this compensatory mechanism can be modulated through dietary intervention.

In conclusion, Nile rats represent a unique model to study T2D: they first exhibit compensation followed by deterioration of $\beta$-cell function and morphology in conjunction with sustained hyperglycemia over a long time course that is consistent with the five progressive stages of diabetes proposed by Weir and Bonner-Weir (2004). Immunohistochemical evidence of impaired proinsulin processing and altered ER chaperone protein behavior is suggestive of ER stress triggered by increased insulin demand. Therefore, our results support that a perturbation early in life (reduced insulin sensitivity and

Published by Bioscientifica Ltd 
increased HOMA-B at 2 months in animals fed chow) results in the subsequent protracted development of T2D. Increasing dietary fiber (Mazuri Chinchilla Diet), and the resultant reduction in caloric density, prevented this perturbation (insulin sensitivity and HOMA-B remained unchanged for at least 6 months), and therefore diabetes. The Nile rat has valuable potential for the study of detailed aspects of early manifestation of glucose metabolism dysregulation and how this might initiate protracted events leading to T2D. Finally, the development and implementation of measures to prevent this ubiquitous devastating systemic disease can only be fully achieved through an exhaustive characterization of these precocious events.

\section{Supplementary data}

This is linked to the online version of the paper at http://dx.doi.org/10.1530/ JOE-15-0517.

\section{Declaration of interest}

The authors declare that there is no conflict of interest that could be perceived as prejudicing the impartiality of this article.

\section{Funding}

This work was supported by the Canadian Institutes of Health Research (CIHR; MOP 125873) to Y S and C B C. Y S is an AHFMR senior scholar (200800242); K Y and $\mathrm{H} \mathrm{H}$ are recipients of scholarships from China Scholarship Council; J G is recipient of a scholarship from the Alberta Diabetes Institute.

\section{Author contributions}

K Y performed experiments, analyzed data, and wrote the manuscript. J G performed experiments. S K performed experiments, analyzed data, and wrote the manuscript. $\mathrm{H} \mathrm{H}$ performed experiments and analyzed data. Y S provided funding, wrote the manuscript, and is the guarantor of this publication. C B C provided funding and wrote the manuscript.

\section{Acknowledgments}

The authors thank Rachel Bryant, Frances Merkosky, and Charlene Sinclair for their assistance with data acquisition, and Erin Pelletier for Nile rat housing care. The monoclonal antibody GS-9A8 developed by Ole D Madsen, Hagedorn Research Institute, was obtained from the Developmental Studies Hybridoma Bank developed under the auspices of the NICHD and maintained by the Department of Biology, University of lowa, lowa City, IA, USA.

\section{References}

Alberti KG, Eckel RH, Grundy SM, Zimmet PZ, Cleeman JI, Donato KA, Fruchart JC, James WP, Loria CM, Smith SC Jr, et al. 2009 Harmonizing the metabolic syndrome: a joint interim statement of the International Diabetes Federation Task Force on
Epidemiology and Prevention; National Heart, Lung, and Blood Institute; American Heart Association; World Heart Federation; International Atherosclerosis Society; and International Association for the Study of Obesity. Circulation 120 1640-1645. (doi:10.1161/ CIRCULATIONAHA.109.192644)

Bolsinger J, Pronczuk A \& Hayes KC 2013 Dietary carbohydrate dictates development of type 2 diabetes in the Nile rat. Journal of Nutritional Biochemistry 24 1945-1952. (doi:10.1016/j.jnutbio.2013.06.004)

Cefalu WT 2006 Animal models of type 2 diabetes: clinical presentation and pathophysiological relevance to the human condition. ILAR Journal 47 186-198. (doi:10.1093/ilar.47.3.186)

Chaabo F, Pronczuk A, Maslova E \& Hayes K 2010 Nutritional correlates and dynamics of diabetes in the Nile rat (Arvicanthis niloticus): a novel model for diet-induced type 2 diabetes and the metabolic syndrome. Nutrition \& Metabolism 7 29. (doi:10.1186/1743-7075-7-29)

Chan CB, MacPhail RM \& Mitton K 1993 Evidence for defective glucose sensing by islets of $\mathrm{fa} / \mathrm{fa}$ obese Zucker rats. Canadian Journal of Physiology and Pharmacology 71 34-39. (doi:10.1139/y93-005)

Chan CB, De Leo D, Joseph JW, McQuaid TS, Ha XF, Xu F, Tsushima RG, Pennefather PS, Salapatek AM \& Wheeler MB 2001 Increased uncoupling protein-2 levels in beta-cells are associated with impaired glucose-stimulated insulin secretion: mechanism of action. Diabetes 50 1302-1310. (doi:10.2337/diabetes.50.6.1302)

Chang-Chen KJ, Mullur R \& Bernal-Mizrachi E 2008 Beta-cell failure as a complication of diabetes. Reviews in Endocrine and Metabolic Disorders 9 329-343. (doi:10.1007/s11154-008-9101-5)

Danaei G, Finucane MM, Lu Y, Singh GM, Cowan MJ, Paciorek CJ, Lin JK, Farzadfar F, Khang YH, Stevens GA, et al. 2011 National, regional and global trends in fasting plasma glucose and diabetes prevalence since 1980: systematic analysis of health examination surveys and epidemiological studies with 370 country-years and 2.7 million participants. Lancet 378 31-40. (doi:10.1016/S0140-6736(11)60679-X)

Deng S, Vatamaniuk M, Huang X, Doliba N, Lian MM, Frank A, Velidedeoglu E, Desai NM, Koeberlein B, Wolf B, et al. 2004 Structural and functional abnormalities in the islets isolated from type 2 diabetic subjects. Diabetes 53 624-632. (doi:10.2337/ diabetes.53.3.624)

Eizirik DL \& Cnop M 2010 ER stress in pancreatic beta cells: the thin red line between adaptation and failure. Science Signaling 3 pe7. (doi:10.1126/scisignal.3110pe7)

Goldenberg R \& Punthakee Z 2013 Definition, classification and diagnosis of diabetes, prediabetes and metabolic syndrome. Canadian Journal of Diabetes 37 S8-S11. (doi:10.1016/j.jcjd.2013.01.011)

Herberg L \& Coleman DL 1977 Laboratory animals exhibiting obesity and diabetes syndromes. Metabolism 26 59-99. (doi:10.1016/ 0026-0495(77)90128-7)

Higa A \& Chevet E 2012 Redox signaling loops in the unfolded protein response. Cellular Signalling 24 1548-1555. (doi:10.1016/ j.cellsig.2012.03.011)

Hong EG, Jung DY, Ko HJ, Zhang Z, Ma Z, Jun JY, Kim JH, Sumner AD, Vary TC, et al. 2007 Nonobese, insulin-deficient Ins2Akita mice develop type 2 diabetes phenotypes including insulin resistance and cardiac remodeling. American Journal of Physiology: Endocrinology and Metabolism 293 E1687-E1696. (doi:10.1152/ajpendo.00256.2007)

Hummel KP, Dickie MM \& Coleman DL 1966 Diabetes, a new mutation in the mouse. Science 153 1127-1128. (doi:10.1126/ science.153.3740.1127)

Kaufman RJ, Back SH, Song B, Han J \& Hassler J 2010 The unfolded protein response is required to maintain the integrity of the endoplasmic reticulum, prevent oxidative stress and preserve differentiation in $\beta$-cells. Diabetes, Obesity and Metabolism 12 (Supplement 2) 99-107. (doi:10.1111/j.14631326.2010.01281.x)

King AJF 2012 The use of animal models in diabetes research. British Journal of Pharmacology 166 877-894. (doi:10.1111/ j.1476-5381.2012.01911.x) 
Ma RCW \& Tong PCY 2010 Epidemiology of type 2 diabetes. In Textbook of Diabetes, edn 4, pp 45-68. Eds RIG Holt, C Cockram, A Flyvbjerg \& BJ Goldstein. Oxford, UK: Wiley-Blackwell.

Matveyenko AV \& Butler PC 2008 Relationship between beta-cell mass and diabetes onset. Diabetes, Obesity and Metabolism 10 (Supplement 4) 23-31. (doi:10.1111/j.1463-1326.2008.00939.x)

Noda K, Melhorn MI, Zandi S, Frimmel S, Tayyari F, Hisatomi T, Almulki L, Pronczuk A, Hayes KC \& Hafezi-Moghadam A 2010 An animal model of spontaneous metabolic syndrome: Nile grass rat. FASEB Journal 24 2443-2453. (doi:10.1096/fj.09-152678)

Noda K, Hattori N \& Okuma Y 2014 Primary central nervous system lymphoma presenting as choreoathetosis. BMJ Case Reports $\mathbf{2 0 1 4}$ article 203353. (doi:10.1136/bcr-2013-203353)

Pfützner A, Pfützner AH, Larbig M \& Forst T 2004 Role of intact proinsulin in diagnosis and treatment of type 2 diabetes mellitus. Diabetes Technology \& Therapeutics 6 405-412. (doi:10.1089/152091504774198124)

Pfützner A, Standl E, Hohberg C, Konrad T, Strotmann HJ, Lübben G, Langenfeld MR, Schulze J \& Forst T 2005 IRIS II study: intact proinsulin is confirmed as a highly specific indicator for insulin resistance in a large cross-sectional study design. Diabetes Technology \& Therapeutics 7 478-486. (doi:10.1089/dia.2005.7.478)

Prentki M \& Nolan CJ 2006 Islet beta cell failure in type 2 diabetes. Journal of Clinical Investigation 116 1802-1812. (doi:10.1172/JCI29103)

Rabiu S \& Rose RK 1997 A quantitative study of diet in three species of rodents in natural and irrigated savanna fields. Acta Theriologica $\mathbf{4 2}$ 55-70. (doi:10.4098/0001-7051)

Rahier J, Guiot Y, Goebbels RM, Sempoux C \& Henquin JC 2008 Pancreatic beta-cell mass in European subjects with type 2 diabetes. Diabetes, Obesity and Metabolism 10 (Supplement 4) 32-42. (doi:10.1111/j.1463-1326.2008.00969.x)

Reaven GM 1988 Banting lecture 1988. Role of insulin resistance in human disease. Diabetes 37 1595-1607. (doi:10.2337/diab.37.12.1595)

Salvalaggio PR, Deng S, Ariyan CE, Millet I, Zawalich WS, Basadonna GP \& Rothstein DM 2002 Islet filtration: a simple and rapid new purification procedure that avoids ficoll and improves islet mass and function. Transplantation 74 877-879. (doi:10.1097/00007890200209270-00023)

Scheuner D \& Kaufman RJ 2008 The unfolded protein response: a pathway that links insulin demand with beta-cell failure and diabetes. Endocrine Reviews 29 317-333. (doi:10.1210/er.2007-0039)

Skovsø S 2014 Modeling type 2 diabetes in rats using high fat diet and streptozotocin. Journal of Diabetes Investigation 5 349-538. (doi:10.1111/jdi.12235)
Spijker HS, Ravelli RB, Mommaas-Kienhuis AM, van Apeldoorn AA, Engelse MA, Zaldumbide A, Bonner-Weir S, Rabelink TJ, Hoeben RC, Clevers H, et al. 2013 Conversion of mature human $\beta$-cells into glucagon-producting $\alpha$-cells. Diabetes 62 2471-2480. (doi:10.2337) db12-1001)

Srinivasan K \& Ramarao P 2007 Animal models in type 2 diabetes research: an overview. Indian Journal of Medical Research 125 451-472.

Steiner DF, Park S-Y, Støy J, Philipson LH \& Bell GI 2009 A brief perspective on insulin production. Diabetes, Obesity and Metabolism 11 189-196. (doi:10.1111/j.1463-1326.2009.01106.x)

Strawbridge RJ, Dupuis J, Prokopenko I, Barker A, Ahlqvist E, Rybin D, Petrie JR, Travers ME, Bouatia-Naji N, Dimas AS, et al. 2011 Genomewide association identifies nine common variants associated with fasting proinsulin levels and provides new insights into the pathophysiology of type 2 diabetes. Diabetes $602624-2634$. (doi:10.2337/db11-0415)

Talchai C, Xuan S, Lin HV, Sussel L \& Accili D 2012 Pancreatic $\beta$ cell dedifferentiation as a mechanism of diabetic $\beta$ cell failure. Cell 150 1223-1234. (doi:10.1016/j.cell.2012.07.029)

U.K. Prospective Diabetes Study Group 1995 U.K. prospective diabetes study 16: Overview of 6 years' therapy of type II diabetes: a progressive disease. Diabetes 44 1249-1258. (doi:10.2337/diab.44.11.1249)

von Berghes C, Brabant G, Biebermann H, Krude H \& Wiegand S 2011 Proinsulin and the proinsulin/insulin ratio in overweight and obese children and adolescents: relation to clinical parameters, insulin resistance, and impaired glucose regulation. Pediatric Diabetes 12 242-249. (doi:10.1111/j.1399-5448.2010.00734.x)

Wareham NJ, Byrne CD, Williams R, Day NE \& Hales CN 1999 Fasting proinsulin concentrations predict the development of type 2 diabetes. Diabetes Care 22 262-270. (doi:10.2337/diacare.22.2.262)

Weir GC \& Bonner-Weir S 2004 Five of stages of evolving beta-cell dysfunction during progression to diabetes. Diabetes 53 S16-S21. (doi:10.2337/diabetes.53.6.1621)

Whitlock KA, Kozicky L, Jin A, Yee H, Ha C, Morris J, Field CJ, Bell RC, Ozga JA \& Chan CB 2012 Assessment of the mechanisms exerting glucose-lowering effects of dried peas in glucose-intolerant rats. British Journal of Nutrition 108 (Supplement) S91-S102. (doi:10.1017/ S0007114512000736)

Yoon KH, Ko SH, Cho JH, Lee JM, Ahn YB, Song KH, Yoo SJ, Kang MI, Cha BY, Lee KW, et al. 2003 Selective beta-cell loss and alpha-cell expansion in patients with type 2 diabetes mellitus in Korea. Journal of Clinical Endocrinology and Metabolism 88 2300-2308. (doi:10.1210/jc.2002-020735)

Received in final form 1 April 2016

Accepted 11 April 2016

Accepted Preprint published online 11 April 2016
(C) 2016 Society for Endocrinology Printed in Great Britain 